\title{
Changing Minds and Changing Laws: How New Zealand Sex Workers and Their Allies Shaped Decriminalisation in New Zealand
}

\author{
Eurydice Aroney ${ }^{1}[0$
}

Accepted: 11 March 2021 / Published online: 23 March 2021

(C) The Author(s), under exclusive licence to Springer Science+Business Media, LLC, part of Springer Nature 2021

\begin{abstract}
Introduction This article provides insight into a rare instance of a collaborative governance approach to sex work that led to the decriminalisation, design and implementation of the sex work policy governance framework in New Zealand with the Prostitution Reform Act 2003.

Methods Drawing on a sample of 17 interviews conducted between the years 2012 and 2019 in addition to associated archival material originating from government and non-government sectors including sex worker representative organisations.

Results It finds that non-sex workers' endorsement for the decriminalisation of sex work was motivated by the New Zealand Prostitutes Collective (NZPC) and occurred primarily within a human rights and harm minimisation framework. But that during the lobbying and parliamentary process, amendments to the Bill emerged that contradicted the NZPC's main goal which was for sex work to be recognised as a legitimate labour activity and for all sex workers to benefit from decriminalisation and policy reform.

Conclusions As such, this article broadens the scope of analysis related to the sex worker rights movement by examining how and why sex workers and their allies came to communicate and act on the impetus for sex work law reform and how it affected policy outcomes.

Policy Implications Those involved in collaborative governance sex work law reform projects could consider adopting Östegren's typology of repressive, restrictive or integrative approaches to sex work law reform in negotiations that concern regulation and policies.
\end{abstract}

Keywords Sex work · Decriminalisation · Sex worker rights movement $\cdot$ New Zealand Prostitutes Collective $\cdot$ Movement allies $\cdot$ Collaboration

\section{Introduction}

On May 13th 2020, the New Zealand Prostitutes Collective (NZPC) Aotearoa New Zealand Sex Workers' Collective announced on its website that, from midnight, New Zealand sex workers could safely return to work under Covid 19 alert level 2 restrictions (NZPC, n.d.). Brothel, street-based and private sex workers all got the green light to open up, along with shops, restaurants, movie theatres, cafes and gyms, proving that as far as the New Zealand (NZ) government was concerned, the sex industry was a business with workers,

Eurydice Aroney

Eurydice.aroney@gmail.com

1 School of Communication, Faculty of Arts and Social Sciences, University of Technology Sydney, Sydney, NSW, Australia employers and customers to be treated no differently to other parts of the economy (Radio New Zealand, 2020). During the lockdown, some street-based sex workers were offered supported accommodation, and others were able to apply for a government wage subsidy, although many avoided doing so out of wariness at having to declare themselves a sex worker inside a government system linked to childcare and taxation. But while the stigma that continues to haunt sex workers may have prevented some from accessing their rights as employees, sex workers' experience in New Zealand during the COVID pandemic is consistent with evidence showing that the decriminalisation of sex work improves sex workers' access to labour and human rights, while reducing the harms associated with HIV/AIDS, violence and exploitation (Decker et al., 2015; Shannon et al., 2014).

Apart from New Zealand, only a handful of jurisdictions worldwide have enacted significant decriminalisation of 
prostitution in law. These include the Australian state of New South Wales in 1995, and more recently the Northern Territory in 2019. New Zealand decriminalised most aspects of sex work with the Prostitution Reform Act 2003 (Abel et al., 2010), but migrant sex work remains effectively criminalised through section 19 of the PRA, which makes it a condition that no visa be granted to a person intending to participate in the sex industry (Prostitution Reform Act 2003). Holders of any temporary class visa granted under the Immigration Act 2009 are also prohibited from engaging in sex work (Immigration Reform Act 2009). Under the PRA, certificates are required for operators of the business of prostitution. This factor is commonly understood among the sex worker rights movement (at least in Australia) to constitute a licensing model rather than decriminalisation. Decriminalisation remains a troublesome term for both sex worker rights activists and academic commentators, as both in New Zealand, and in other jurisdictions such as NSW, elements of regulation or licensing have been introduced or re-introduced, for example at local government level (Crofts et al., 2012). Regardless of these caveats, it is widely acknowledged that in the design, lobbying, ratification, and review of the PRA the NZPC were involved in a collaborative governance approach to prostitution law reform to achieve what has since been termed an integrative framework for sex work law and policy. As such, New Zealand can be seen as a laboratory for the collaborative governance of sex work (Östergren, 2017; Rottier, 2018).

Previous research on the decriminalisation of sex work in New Zealand has largely focused on how law reform has impacted on sex workers. This article focuses on their allies, seeking to gain insight into how and why they participated in this innovative example of collaborative governance by examining the motivations, activities and attitudes of a selection of key players in the law reform process, primarily nonsex workers who were aligned with the New Zealand Prostitutes Collective during the period 1988-2008. Employing a mixed methods approach, it shows that the positions of non-sex worker allies towards those in the sex industry were profoundly influenced by their involvement with the NZPC and that their support and advocacy contributed importantly to sex work law and policy reform.

In other research, Fuji Johnson has applied the term policy community (Coleman \& Perl, 1999) to classify and conceptualise similarly placed actors who worked towards sex work public policy initiatives in Vancouver. This concept enabled the research to "focus on relationships and not merely structural and strategic linkages" and allowed it to "capture nuances concerning changing dynamics and their implications for policy" (Johnson, 2015, p.5). That research found that even where community members were antagonistic towards each other, they were at times able to converge on principles of harm reduction to achieve a range of initiatives aimed at improving the health and safety of sex workers.
Similarly, this research looks at representative players from a policy community in New Zealand who also converged on principles of harm reduction. Here, however, the aim is to reveal how collaborative governance enabled this $\mathrm{NZ}$ policy community to shift public attitudes towards and understandings of the sex industry in order to effect actual law reform.

This article contends that collaborative governance occurred to a high degree in New Zealand, and that through this process, the allies interviewed for this research came to accept that some people freely chose and experienced sex work as an occupation. Nevertheless, in the re-drafting of the Bill and the parliamentary process, harm reduction arguments and political concerns about human trafficking led to amendments that contradict the broader aspirations of the sex worker rights movement. While these amendments did not prevent the NZPC's continued support for the bill, the methods and arguments employed by some allies did generate cause for reflection about the collaborative governance project.

As a result, this article includes suggestions on how the collaborative governance experience could be enhanced. For example, it builds on arguments which propose that the use of the term decriminalisation be restricted to the repeal of criminal laws as they apply to the sex industry, and not as a policy term (Abel, 2018). It recommends that sex worker organisations and their allies adopt an alternative typology of sex work policy, using it as a tool in both the design and communication of their law reform objectives (Benoit et al., 2019).

In closing, it seeks to draw broader conclusions about both the benefits and the limits of collaboration between sex worker rights organisations and their allies in pursuit of legal and policy reform.

\section{Methodology}

This research combines qualitative methods that include ethnographic observation, archival research and the audio recording of semi-structured in-depth interviews with sex workers and their allies. Most interviews were conducted during 3 weeks in February 2019. Over this period the author observed and at times contributed to NZPC office activities in Wellington and Auckland. In particular, she worked alongside NZPC staff in assessing and sorting NZPC archives with a view to curating additional material for an online historical timeline. This author has a long history with the NSW sex worker rights community as an activist, chronicler, researcher and former sex worker. This gave her privileged access to the NZPC, their contacts and staff, as well as lived insight into NZPC organisational history and operations. 
Interviews were conducted with NZPC staff (n6) and associated sex worker activists (n2) along with non-sex worker allies identified by the NZPC as having supported the decriminalisation of sex work and the NZPC in their campaigning for law and policy reform (n9). One nonsex worker ally, Warren Lindberg, was interviewed with assistance from the NZPC's Annah Pickering, the others by this author alone.

As the non-sex worker interviewees came to support the NZPC's campaign for decriminalisation through several pathways, questions to them were tailored to their specific role or involvement with the collective. Each was asked about their motivation for engagement, their role in the law reform process, how they came to know sex workers, the sex industry and the various laws and policies that apply to it. They were asked to consider and reflect on how their connection with the NZPC and sex workers may have influenced their attitudes to, and perceptions of sex work and law reform. Interviewees with current or former connections to the sex industry (which included staff of the NZPC) were asked about their involvement and history with the NZPC. Four of these interviewees were asked about their participation in the law reform process. All interviews were transcribed, categorised and analysed for shared themes.

The NZPC archives which include published and unpublished materials, correspondence and media reports as well as the NZPC's Siren magazine were important cross-referencing sources for this article, as were NZ Hansard and NZ government documents and policies. This article also features extracts from an interview with Catherine Healy, national coordinator of the NZPC, which is part of a collection of 19 expansive oral histories with NZ sex workers recorded during the years 2009-2016 and held by the Alexander Turnbull Library in Wellington (Wilton, 2009-2016), and since published in an edited version (Wilton, 2018).

The non-sex worker allies of the NZPC interviewed for this paper are drawn from a large and disparate group of social actors from the NGO, government and party-political sectors who aligned themselves on occasions with the NZPC. Their engagement with the NZPC was shaped by the political and social opportunities extended to them by their occupations and professional status, community engagement and activist roles. These were further complicated by evolving careers, shifting institutional roles and, in some cases, political ambitions.

In their attempts to represent a stigmatised and-in most jurisdictions in the world-criminalised constituency, sex worker rights organisations are routinely disregarded by governments (Levy-Aronovic et al., 2020). Accordingly, non-sex worker interviewees are identified in this article with their full names, along with accounts of their former and current professional standing (where relevant) to emphasise their willingness to be identified with a social movement struggling for legitimacy. Interviewees with sex work and sex industry experience were given the opportunity to use pseudonyms in recognition of the ongoing stigma they experience.

\section{Collaborative Governance and an Alternative Typology of Sex Work}

In a recent comparison of prostitution laws and governance approaches in 21 European countries since the middle of the nineteenth century, Wagenaar found that none had achieved their intended purpose, which was to reduce or contain the prevalence of sex work (Wagenaar, 2017). Instead, these policies had eroded the human and labour rights of sex workers. This same research asserts that any improvement in the current situation must be based on a strategy of collaborative governance with sex worker advocacy organisations. Sex worker rights organisations have also emphasised the imperative for sex workers not just to be consulted on policy, but involved in its design, implementation and review (Geymonat \& Macioti, 2016). Rottier asserts that this rarely practiced approach to prostitution policy was first put into practice in New Zealand where government and non-government bodies worked closely with the New Zealand Prostitutes Collective to enact the Prostitution Reform Act (Rottier, 2018).

Collaborative governance is defined as a "governing arrangement where one or more public agencies directly engage non-state stakeholders in a collective decision-making process that is formal, consensus-oriented, and deliberative and that aims to make or implement public policy or manage public programs or assets" (Ansell \& Gash, 2008, p.544). This type of governance often emerges in policy areas where there is a history of failure in achieving reform. As it applies to sex work, Wagenaar et al. have interpreted this approach as meaningful consultation and authentic dialogue between sex workers, government and other stake holders (Wagenaar et al, 2017). The NZPC were involved in the design and review of the PRA and continue to defend it and other laws to protect and promote the rights, welfare and health and safety of sex workers (Sweetman, 2017). Thus, NZ is a particularly important case study, a laboratory of the collaborative governance of sex work.

A collaborative mode of governance is also an essential precondition for what has been termed an integrative framework approach to prostitution policy design (Östergren, 2017). This descriptor is one of a tripartite typology proposed by Petra Östergren which categorises approaches to prostitution governance as either repressive, restrictive or integrative. This nuanced categorisation allows for how the various tools of governance are formulated and implemented and how they then impact the sector over the short and long term, acknowledging that policy in this area is multi-faceted and dynamic. 
According to Östergren (2017) and others, instrumental terms such as legalisation and decriminalisation used to categorise sex work policy regimes have failed to adequately describe and calculate the effects of policies and regulation on the everyday operations of sex work (Scoular, 2010; Skilbrei $\&$ Holmström, 2016). This can be seen in New Zealand, where under a policy regime described as decriminalisation, two local councils have challenged aspects of the PRA by enacting bylaws that restrict both street-based sex work and small owner-operated brothels (SOOBS). Warnock and Wheen claim that amendments to the PRA demonstrated the "reassertion of legal moralism in the control of sex work. In practical terms, brothels became heavily regulated and were pushed into marginal areas primarily because public submitters were opposed to sex work per se" (Warnock \& Wheen, 2012, p.416). These and other fault lines in the PRA expose the unsatisfactory nature of using terms like legalisation and decriminalisation as policy descriptors when according to Östergren "there is no consensus on what exactly is meant by each term or on what basis is it used. Nor is there a common understanding as to what constitutes a particular category and how it differs from the others" (Östergren, 2017, p.2). Sex workers in Australia are all too aware of the effects of this lack of consensus over the term decriminalisation. The peak national sex worker rights organisation in Australia, Scarlet Alliance, recently published a briefing paper that reflects years of internal discussions about what the term should include. It calls for the repeal of sex work-specific criminal and licensing laws and regulations, repeal of sex work-specific migration restrictions, removal of police as regulators, and the extension of anti-discrimination and anti-vilification protections to sex workers so that they can lead "free and self-determined lives" (Scarlet Alliance, 2021).

Some academic researchers have sought to move beyond debates over the definition of decriminalisation. Instead, Joep Rottier applied Östergren's (2017) typology of repressive, restrictive and integrative approaches, using it as a tool to assess and evaluate the PRA in an exhaustive analysis of the 'New Zealand Model' of law reform (Rottier, 2018). Here, he acknowledged the core role of decriminalisation (the removal of criminal laws applying to the sex industry) but applied the term integrative framework to describe New Zealand's approach to sex industry policy implementation under the PRA. In so doing, he demonstrated its usefulness as a tool for researchers in assessing, evaluating and comparing prostitution polices. But as will be shown in this article, this typology could also be usefully applied by those involved in lobbying for policy reform.

\section{Barriers to Collaborative Governance}

A collaborative approach to prostitution governance implies government meeting with, and listening to, stakeholders and their representatives. In the case of sex work, it also means recognizing SWROs as legitimate stakeholders in any law reform effort. Partnerships between SWROs, NGO's and public health bodies in places like NZ, Australia, Thailand, India and Africa have been shown to be extremely effective in preventing harm (Donovan et al., 2012; Kerrigan et al., 2015). However, meaningful consultation and collaborative opportunities have rarely been extended to the political and policy sphere where the contribution of sex workers and their representative bodies would have the most impact. In the main, SWROs continue to encounter significant barriers in their efforts to communicate with governing and regulatory bodies on prostitution law reform (Global Network of Sex Work Projects, 2020).

These barriers are linked to abolitionist discourses that position sex workers first and foremost as victims, based on a view that those involved in prostitution lack agency (Vanwesenbeeck, 2017). Neo-abolitionists maintain that all prostitution is violence against women and reproach activists who call for decriminalisation as being subject to false consciousness about the harm caused by sex work (Raymond, 2018). Accusations that SWROs and the human rights groups that support them are co-opted by the 'pimp lobby'-an abolitionist term that applies to those who manage and own businesses that employ sex workers-are common (Phipps, 2017). Neoabolitionists are also inclined to conflate sex work with sex trafficking and claim that both are promoted under decriminalised and legalised prostitution policy models (Farley, 2009). They instead claim to support the decriminalisation of 'prostituted people', while at the same time calling for the criminalisation of clients and third parties.

The criminalisation of clients and third parties, sometimes referred to as the 'end demand' or 'Nordic model', was vigorously canvassed by Melissa Farley in her brief visit to New Zealand in 2003, prompting some politicians to advocate for the criminalisation of clients as an alternative to decriminalisation (New Zealand Government, 2003).

Sex work, its locale and third-party associates are frequently criminalised, so that in representing the interests of those involved in the sex industry, sex workers and others can expose themselves, their dependents, their workplaces and associates to criminal charges (Jackson, 2019). Though the socio-economic and cultural context in which they operate differs from country to country, sex workers are well aware that, under a criminalised regime, political mobilisation increases their exposure to harm: at its most extreme, activists have been murdered in attempts to organise (Smith \& Mac, 2018).

Decriminalisation, on the other hand, has been shown to enable the mobilisation of sex workers, which in turn encourages them to form organisations and participate in law reform. This happened in the Australian state of NSW which decriminalised street-based sex work in 1979 (Frances \& Gray, 2007). Emboldened by this reform, sex workers in 
NSW founded a chapter of the Australian Prostitutes Collective (APC) in 1983. The APC's research alliance named the Task Group on Prostitution produced ground-breaking studies that in turn generated the policy and regulations underpinning the decriminalisation of sex work in NSW in 1995 (Aroney \& Crofts, 2019; Perkins \& Bennett, 1985).

There is no guarantee that policy makers will engage with SWROs even where organisations are well established. In the state of South Australia in December 2019, a Bill to decriminalise sex work became the 13th unsuccessful attempt at reform since 1980 (South Australian Government, 2019). Sex worker activists involved in lobbying for this Bill report that 16 out of 24 parliamentarians who voted against it refused to meet with the Sex Industry Network (SIN), the sex worker peer-run organisation. SIN has been funded by South Australian governments to deliver peer-based HIV/AIDS/STI preventative programs since 1987 , yet politicians were reluctant to hear SIN's arguments for reform, which included concerns about the attitudes and actions of the South Australian Police force (Diamond, 2019).

The funding of the NZPC in 1988 acknowledged at the highest possible level that sex workers were best placed to prevent HIV/AIDS taking hold in the sex industry. Until 2003, however, NZPC employees serviced and assisted sex workers who were either criminalised through the act of soliciting, or working in places where third party involvement was criminalised. Although many MPs in New Zealand supported the NZPC during the campaign for the PRA, MP Brent Catchpole (NZ First) joined others who opposed the bill by calling into question the integrity of the NZPC in parliament saying that it was "the one organisation that is out there promoting prostitution and recruiting young people into it, under the guise of providing them with a service" (New Zealand Government, 2003, n.p.).

Under such difficult, and at times hostile circumstances confronting sex worker rights organisations and activists across the globe, it is significant to explore how the NZPC were able to persuade and collaborate with influential and high-profile allies to support them and the decriminalisation of sex work.

\section{Elbows on the Table, Feet in the Door: from Collaboration to Integration}

\section{Allies' Knowledge About the Sex Industry}

When evaluating the effect that the collaborative process had on the allies of the NZPC, it is important to first clarify their prior understandings of, and attitudes towards sex work. In this, most allies were no different to the general population in acknowledging that they knew little about the sex industry, the laws that applied to it or those involved. Five of the nine non-sex worker allies identified mainstream media and popular culture, along with the casual observation of street-based sex workers, as the primary sources of their knowledge about sex work prior to their contact with the NZPC. For instance, when former executive director of the New Zealand AIDS Foundation (1986-98) Warren Lindberg met Catherine Healy on the National Council on AIDS in 1988, he knew "bugger all" about sex work, only that "prostitutes turned up in fiction" (Lindberg, 2019, n.p.). The same applied even where interviewees had worked in health-related professions or provided services where sex workers were (wittingly or unwittingly) under their supervision. Interviewee Gill Greer was appointed as the Assistant Vice Chancellor at Victoria University in the 1990s and, while in this position, became aware through her staff that some students were subsidising their studies by way of sex work. But it was only a decade later through her contact with the NZPC in her role as Chief Executive of Family Planning in New Zealand (FPNZ) that Greer had reason to reflect on how criminalisation directly affected them (Greer, 2019). Family Planning sexual health clinics under her direction had been asked to provide to government an identification number and personal details for each of their clients that would link through to a larger data base. Clinic nurses and doctors refused, saying that this would only increase the vulnerability of sex workers and risk loss of confidentiality. The NZPC, which had facilitated sex workers' access to FPNZ clinics, had alerted staff and Greer to how criminalisation and stigma were linked to the health and wellbeing of sex workers, and consequently Family Planning New Zealand refused to provide sex worker details to the government (Greer, 2019).

It might be assumed that those tasked with enforcing the law would have had better insight into how sex workers were impacted and how the sex industry operated prior to the PRA. But according to former Acting Deputy Police Commissioner of New Zealand Paul Fitzharris, the attitude of officers like himself who were trained in the 1960s was that the enforcement of prostitution laws was simply "their job" (Fitzharris, 2019, n.p.). It was understood that, although many aspects of the sex industry were criminalised, the police would use their own discretion as to whether to enforce the laws. To "keep their thumb on it and know what was going on without trying to exterminate it" as he described (n.p.). The effects of this approach on those under the thumb were not really considered. As he told me "to be honest it was seen as a 'fun bit' of the police... it was very interesting, but we never read any academic tomes on this" (Fitzharris, 2019). Fitzharris' long journey from police cadet in the 1960s to the Chair of the Prostitution Law Review Board over 40 years later 
involved a 2-year-long stint policing nightclubs, pornography and prostitution for the Wellington Vice Squad in the late 1970s. While it was near impossible for police to charge street-based sex workers, because clients (those solicited) had to give evidence that they had experienced offence under the law, it was relatively easy to lay charges against trans sex workers who would be found guilty of male homosexuality under the provisions of the Crimes Act 1961. Using this provision, Fitzharris twice arrested Carmen Rupe, a well-known trans sex worker and activist, one-time Wellington Mayoral candidate, entertainer and proprietor of a coffee shop that doubled as a small brothel. Apart from the disproportionate charges against trans and male sex workers, there were, according to Fitzharris, very few prosecutions laid in the 1970s, although this did not mean that the police were seen as harmless; "we were there to enforce these laws so they would fear us I imagine and probably despise us" he told me (Fitzharris, 2019, n.p.). Apart from his contact with Carmen, Fitzharris had little direct contact with sex workers until 2008 when he was appointed as chair to the Prostitution Law Review Board.

Interviewee Jan Logie came into contact with sex workers when working in a women's refuge, but as she explained, this did not result in her having a broad knowledge of the prostitution laws, or what was involved in sex work. It was only through her support for the NZPC during its decriminalisation campaign in the early 2000s in her role as CEO of the Young Women's Christian Association that she realised what was at stake for sex workers, although an incident in the 1990s gave her some pause for thought. Being a student at that time and short of money she had applied for a job as a sex worker "it would have involved sleeping with the guy who was interviewing me, and I was like ... mmm (laughs) not sure that quite fits with how I'd see this working" (Logie, 2019, n.p.). In her role as Member of Parliament for the Green Party of Aotearoa and NZ's Parliamentary UnderSecretary with the Portfolio of Justice, Sexual and Domestic Violence in 2019, her disclosure that she had once considered being a sex worker could be seen as an indication that contact with the sex industry has become less stigmatised since the PRA.

Logie was one of two interviewees who casually revealed personal and up-close experience with the sex industry as a young person. The other was New Zealand's first Pasifika female MP Winnie Laban, now the Assistant Vice Chancellor for Pacifica Victoria University of Wellington. Laban recalled that in the 1960s, her uncle opened the Purple Onion, one of Wellingtons first burlesque (and later strip) clubs where many of the performers were 'drag queens' (Laban, 2019 n.p.). Winnie Laban's uncle was known among family as Fa'afafine; that is, someone who identifies themselves as having a third-gender or non-binary role in Samoa,
American Samoa and the Samoan diaspora. As she told me, "I've got lots of family who are gay and lots of cousins who are Fa' afafinie and we've never seen it as a major issue" (n.p.). Laban's family were also devout Christians and she had attended a prestigious boarding school, but she recalled on one occasion her uncle collected her from school in his work vehicle, wanting young Winnie to lend a hand by making toasted sandwiches for Purple Onion club patrons; "can you imagine there were all these naked women (painted) on the van!" (n.p.). Her family befriended the club's entertainers who told Laban that they enjoyed their work despite being excommunicated from their own families. As she revealed to me "people don't realise that we mixed a lot with prostitutes and people who worked in burlesque clubs, that was part of our growing up which I think people will be surprised when they know this" (n.p.).

Senior Lecturer in Criminology Lynzi Armstrong was an exception amongst the allies in that she became interested in the debates around sex work while completing her Masters' degree in Scotland in 2006: "I'd never heard of decriminalization before as a framework I didn't know anything about it and I just thought wow that sounds really interesting" (Armstrong, 2019, n.p). For Armstrong, researching the impact of decriminalisation in New Zealand has become more than a job "I actually am an activist and that's how I see myself, I really don't buy into the idea that researchers are kind of robots who have no views and no opinions and are objective I think that pretending to be objective is actually quite dangerous particularly where it comes to an issue like this" (n.p.)

To summarise, it was only through the process of becoming involved with the NZPC that most interviewees were motivated to engage with the sex industry and become acquainted with its laws and regulations. All interviewees bar one sought evidence-based research about various approaches to prostitution law and policy only in response to their engagement with the NZPC and the law reform process. Therefore, the NZPC could be seen to have played an important educative role for allies in their support for law reform.

But given their general ignorance about the sex industry and the people working in it, what prompted non-sex worker allies to become involved in the process of law reform, and what was the nature of their contributions?

\section{Getting Involved and Taking a Role: NGO's and Non-party Political Allies}

The allies were motivated to support and act with the NZPC through a number of personal and professional pathways. Some came into contact with the collective through their work with NGOs and social institutions, others through membership on committees with shared activist goals. 
As the CEO of the Young Women's Christian Association, Jan Logie had inherited her association with the collective from the organisation's previous executive but recalled that the YWCA's support for the NZPC was encouraged by the association's younger membership:

...recognizing that sex work is a female dominated industry and that it's always been there and if we cared about the wellbeing and safety of the women doing the work then enabling them to make access...freely access health care and the support of the police and be able make choices in their life that would be easier without criminalization. (Logie, 2019, n.p.).

As the debate around the Prostitute Reform Bill (PRB) gathered steam, Jan Logie became an active and visible supporter of the NZPC, speaking alongside them on panels at heated community 'town hall style' meetings as well as in the media. But support for decriminalisation within the Young Women's Christian Association (YWCA) was not uncontroversial-some members worried that it would be seen as an endorsement for sex work. To be persuaded, they needed to see decriminalisation as part of a harm reduction strategy:

....it was about recognizing that criminalization was a barrier for women leaving the industry and so while they may not have approved of sex work at all that they could understand that if we were to support people out of it then actually decriminalizing could help with that. (Logie, 2019, n.p.).

Other allies came into contact with the NZPC following their appointment to NGO boards or government committees. This was the case with Warren Lindberg who, in his role as the Executive Director of the NZ AIDS Foundation, met NZPC's Catherine Healy when they were both appointed to the National Council on AIDS (NCOA) in 1988. This body was tasked with producing an overall strategy for dealing with the epidemic. As Warren Lindberg remembers, the NZPC immediately added the decriminalisation of sex work to its agenda. As he told me "you cannot provide health promotion to people in hiding. So (that meant) decriminalisation of homosexual acts, decriminalisation of the possession of needles and syringes and the decriminalisation of the sex industry" (Lindberg, 2019, n.p.). The last reform would prove the most difficult to achieve because as Lindberg explained, it was on the end of the list of three:

By that time (mid 1990's) AIDS was no longer seen as the crisis that it had been in the 1980s and so this was about accepting prostitutes as workers, with the same rights as workers as anywhere else so there was a bit of reservation because of the deeply seated prejudice about being paid money for sex. (Lindberg, 2019, n.p.).
To back political demands for law reform, the NCOA needed to provide evidence-based research that showed that the current laws were likely to exacerbate the reach and effects of HIV/AIDS. But as Lindberg explained, this was made difficult by the "research vacuum" (n.p) that enveloped these groups in New Zealand. Across the ditch in Australia it was a different story. There, research was already being produced on the public health consequences of HIV/AIDS for sex workers (Harcourt \& Donovan, 1996).

But more localised research would be needed for the support of decriminalisation in a robust law reform process. As a consequence, the NZPC began to form links with researchers including those with the Department of Public Health and General Practice, University of Otago, Christchurch School of Medicine. Some years later, this research would draw criminologist Lynzi Armstrong to New Zealand. As Lindberg remembers, Catherine Healy recognised the value of research to sex workers and their lobbying "we were all educated and we weren't afraid of academics or politicians for that matter, although some of them were afraid of us" (Lindberg, 2019, n.p.).

According to Lindberg, the NZ AIDS Foundation appointed him as Executive Director because he was "openly gay" and would speak to the media from that position (n.p.). Similarly, some NZPC staff were also prepared to acknowledge their lived experience. In the 1980s and 1990s, this meant that Warren Lindberg, Catherine Healy and others like them were on the frontline of hostile media attacks fuelled by a community-wide fear of HIV/AIDS and a long-held prejudice towards gays, intravenous drug users and sex workers. Catherine appealed to Warren for his advice in dealing with journalists and remembered that he instructed her to answer their questions directly. Any deflection would make journalists suspicious. Having a key message and knowing how to place it in any exchange would also be valuable. He also encouraged her to meet face to face with people at every opportunity and to be reasonable, a quality he recognised as part of Catherine's nature, "she is always...not cautious ...cautious shows a bit, but thoughtful and considered in what she says, that she doesn't bad mouth people, and I think that goes a long way to being accepted by people who don't know you" (Lindberg, 2019, n.p.).

Under Warren's mentorship, Catherine quickly built a reputation as an informed media expert, a reliable and accessible source on the sex industry and not just in New Zealand. In the 1990s, Warren and Catherine travelled to Vietnam on behalf of the World Health Organisation to advise the Vietnamese government on the effectiveness of peer education for those at risk of HIV/AIDS.

Common to all allies was a commitment to human rights and a recognition of the harms caused by the criminalisation of sex work as primary motivating factors for their support of sex work law reform. 
Catherine Healy's steady leadership as the face of the NZPC in mainstream and alternative media, her lived experience as a sex worker and her role in encouraging sex workers and the NZPC to participate in and contribute to research were also identified by interviewees as having galvanised their involvement with the NZPC and support for the decriminalisation of sex work. In 2018, Healy was made a Dame Companion of The New Zealand Order of Merit for her services to the rights of sex workers.

But interviewees' high regard for Catherine Healy also extended to other NZPC staff and associated activists, and as will be shown, these connections led to the crucial political intervention needed for law reform.

\section{Building a Political Constituency: Political Allies and Advisors}

Though partnerships were formed between sex workers and non-sex workers throughout the NZPC's history, at no time were they more critical than in the campaign period leading up to the parliamentary debates and the passage of the PRA. Those wanting a more detailed account of the origins and passage of the PRA will want to refer to Barnett et al. (2010), but here, the focus is on how and why alliances were made between the NZPC and other social and political actors, and whether and to what effect these alliances enabled a collaborative governance approach to sex work policy.

In this section, we hear from the NZPC, sex workers and their allies who were directly involved in the lobbying and campaign period which for the purpose of this paper occurred between 1996 and 2003. People like 'Jenny' who was directed to talk to a politician unsure of his position just hours before the final vote:

He said to me 'Tell me something, what is this new bill going to do for Māori?' and I said to him 'Well I've been working for many years and from Māori to Māori' I said 'I'm going to ask you, you're the politician, what the hell is the current bill doing for Māori? You give me a reasonable answer to that and then I'll understand where you're coming from.' Well, he couldn't answer that because it was doing nothing. (Jenny, 2019 - former New Zealand sex worker, brothel owner and activist).

Last-minute lobbying in the New Zealand Parliamentary bar contributed to a campaign led by Tim Barnett who was elected to NZ parliament in 1996. He had come to NZ via the UK where he was known by the media there as 'Britain's first professional homosexual', the first person to work full time on lobbying for lesbian and gay rights. His initial contact with sex workers in New Zealand was through Catherine Healy when he became a co-member of the AIDS Foundation Board (1992-1995). But in his electorate of
Christchurch, it was NZPC Christchurch co-ordinator Anna Reid whose idea it was for the NZPC office to host open house drinks for the community each Friday night. Barnett was just one of a diverse guest list that included academics, business people and sex industry workers who mixed together on these occasions, "Anna used to be such a great weaver of relationships between the NGO sector and the sex worker movement down there and she just became part of our lives" (Barnett, 2019, n.p.)

It became obvious to Barnett that in a city with a large street-based sex worker presence and around 15 illegal brothels "the law was clearly wrong, so that gave me a sense that here was something that I could get involved with" and the staff of the NZPC had already laid the ground for his campaign "there were a lot of relationships between MPs and the collective. The NZPC often had very part time workers ...... there might have been eight [NZPC employees] jobs right around the country but there seemed to be a lot more [of NZPC staff] than that" (2019, n.p.). According to Barnett, established relations between MPs and the NZPC meant that the gathering of initial support for a decriminalisation bill had already occurred "I didn't need to do anything" he said (n.p). And the NZPC were not only speaking with politicians. By the mid-1990s they had enlisted community support for overhauling NZ's prostitution laws from a number of organisations including the Young Women's Christian Association, the Business and Professional Women's Federation, the National Council of Women, the Council of Trade Unions, the Māori Women's League and a number of individual Catholic nuns and church leaders. In 1998, Tim Barnett, Catherine Healy and Hon Katherine O'Regan visited NSW where decriminalisation had already been adopted and met with politicians like Peter Collins and Pat Rogan who co-chaired the NSW Select Committee into Prostitution as well as Professor Basil Donovan, one of Australia's most prominent researchers on sex work and public health. Finally, in 2000, Barnett introduced a private members bill to parliament. Here too, the NZPC had laid the ground by producing a draft decriminalisation bill in 1994 .

Although Barnett had socialised with sex workers at the NZPC office in Christchurch and met with them as their local MP, he admitted that the reality of sex work was not obvious to him until he heard sex workers present their testimonies to the Justice and Law Reform (Prostitute Reform Bill, 2003, NZ). "One who was quite new to sex work said how in the first few weeks she spent most of the time sitting on a bed listening to men and their various traumas and said she felt like a social worker who went 'all the way'" (Barnett, 2019, n.p.). Listening to their testimonials, he came to the realisation that in sex work "...there was a lot more about caring and understanding" and that "this was fascinating and kind of logical" (n.p.). Barnett recounted this story many times during the 
campaign because it highlighted "the contrast between the assumption and the reality" of sex work (n.p.). He also became aware that peoples' experience with sex work and sex workers was more common than he'd originally understood "people close to me began to tell me stories of themselves and others in their families.... we're not just talking about some people "over there"” (n.p.).

As Barnett's knowledge about sex work expanded so did his apprehension about what he would face in parliament. While he felt that many politicians were supportive of change, he knew that some feared a backlash from voters in their electorates. He needed to keep reminding them that a conscience vote was not about second guessing the safety of their electoral seats. New Zealand had a history of passing socially progressive legislation, homosexuality had been decriminalised in 1986, but for Barnett, "it felt like this was going to be the first big debate that didn't get through and the numbers were as tight as you can get" (Barnett, 2019, n.p.).

There was according to Tim Barnett no overall strategy for the campaign, but for Barnett, the main rationale for reform had to be harm minimisation and consequently he would have his colleagues consider two things:

What do I think if my daughter or son was a sex worker? What would I want? The first thing I'd want is for them to be safe, so therefore I want the law to be as fair as possible. The second thing is that if I want them to get out of the sex industry properly, well, if they're trapped in a semi- or completely illegal industry, then they're unlikely to get out so easily, and so I want it to be as open and as protected as possible. (Barnett, 2019, n.p.).

But for the NZPC's Catherine Healy, Barnett's emphasis on this aspect of harm reduction, veered too close to the belief that sex work, is inherently harmful:

Harm minimisation, harm reduction was a useful term for politicians, and certainly Tim Barnett was happy talking about harm reduction. He knew we weren't. You know, the word 'harm' in there - we talked about enhancing occupational safety and health, not harm reduction. It's not a comfortable fit for us. (Wilton, 2009-2016, n.p.)

Following 20 years of successful public health initiatives and service to the sex industry in a quasi-criminal environment, the NZPC and other sex workers were clearly of the opinion that 'sex work is work' which positions sex work as a legitimate occupation and the people in it as having agency as opposed to being victims of abuse in need of rescuing (Healy et al., 2017). Healy observed that under pressure from NZPC, Barnett drew back from a harm minimisation approach, but the line was pursued by others including the Minister for Immigration Leanne Dalziell, who introduced a Supplementary Order that banned temporary visa holders from working in the sex industry (Armstrong et al., 2020). The political justification was that the amendment would ensure that New Zealand not be seen as an easy destination for traffickers-but there was no evidence of sex work trafficking in New Zealand at that time, and research has found little since (Roguski, 2013). Interviewee Lynzi Armstrong says that the PRA leaves migrant sex workers without their rights, but with a heightened risk of exploitation, and this makes it very difficult to argue that the PRA is 'full decriminalisation' (Armstrong et al., 2020).

The Bill moved through a staged three year-long parliamentary process: two debates decided on whether it should proceed, the last on whether the Bill would be adopted. All three were voted on according to conscience. By the time the third came around, sitting dates were forever changing and the vote narrowing. According to Healy, Section 19 was presented to the NZPC by Barnett as a fait accompli at the $11^{\text {th }}$ hour leading up to the final parliamentary vote "our visceral reaction was that it was wrong and that it was going to cause harm and we wanted to meet with her [the Minister] to discuss it" (Healy, 2019, n.p.). Migrant sex worker needs had long been part of the NZPC "we had special clinics where we worked to accommodate the Thai sex workers who started coming down in the late 80's... we had outreach workers and you know so we had a great knowledge of the migrant community and an awareness of the issues that were there at that point" (Healy, 2019, n.p.). For the NZPC, these did not include the risk of trafficking or forced labour conditions. But Barnett insisted that the Minister would not meet to discuss it. This further disturbed Healy because Dalziel had supported the NZPC for several years and come to their events, they had been confident of her support. Instead, Healy heard "a comment that came back which was that she felt she'd been captured by us... by a ... I forget the particular wording.... but words to the effect by a 'non-representative' group. It left you with the feeling that we weren't the real deal sex workers" (n.p.).

The NZPC knew that dealing behind the scenes about amendments had continued "with the Minister of Justice for example around the zoning so we were fully aware of the nuanced trading stuff that was occurring to get people to come on" (Healy, 2019, n.p.). At no time did the NZPC consider pulling their endorsement for the Bill, but in their meetings with allies, they did have a bottom line from which they would not be moved. This centred on street-based workers:

...who were Māori and who were being arrested most frequently and they were for the most part trans workers...we wanted to make sure that street-based sex 
work was completely decriminalised because that's where the soliciting laws were being applied most heavily and frequently so we had that as our kind of benchmark. (Healy, 2019, n.p.).

Besides this unspoken bottom line, there had been no agreement between the NZPC and their political allies about whether or even how they would negotiate on proposed amendments:

... first we had a vision of repeal all that legislation much the same as homosexual law reform. And to us that was our point that's where we thought oh that will be easy, we just need a blank page. You know repeal the legislation get rid of it. But then it got far more complicated. (Healy, 2019, n.p.).

Decriminalisation as an approach to sex work law and policy reform had only ever really been tried and tested to a significant degree in NSW Australia, so perhaps, it was not surprising that there was a gap in the research on how to approach the dynamics of agenda setting and the selection of policy instruments and regulatory measures. As Healy observed:

...you know it was very, very hard to get that detail ...because I think maybe even in NSW people we'd sought advice from weren't around you know they weren't involved in the building of it or didn't have the nuanced explanations. (Healy, 2019, n.p.).

For Barnett, this gap was exacerbated by a frustration with the term decriminalisation. In his introduction to the second reading of the Bill in February 2003, he attempted to summarise the process of decriminalisation as a four-stage process, cautioning that "few words are as confusing as 'decriminalisation' and 'legalisation"' (New Zealand Government, 2003). Confusion and argument about the meaning of these terms hijacked parliamentary debates. While calling for decriminalisation had been useful as a social movement blanket slogan, it had clearly failed to show the road ahead. As Healy pointed out, they were building the laws as they went along, different typologies of sex work required different regulations, and there was not an even playing field. Broadly, they knew what they wanted:

...we wanted anonymity obviously we didn't want registers and we didn't want coercive intersections where sex workers had to stump up to officials. We didn't want an inspectorate either for that reason. We wanted a relationship - to make sure we had a voluntary relationship. (Barnett, 2019, n.p.).

In response to this-and wanting to make clear the differences between these approaches-Barnett decided to enlist sex workers and the NZPC in a single-minded strategy requiring a united effort.

\section{Storytelling}

Through the select committee and his contact with the NZPC, Barnett heard a wide variety of testimonies not only from sex workers but from clients including those living with disabilities. Often supported by their families, they wanted to be able to access sex workers without fear of criminalisation and were prepared to lobby publicly. Barnett saw the value in airing these and other less obvious perspectives about the impact of the current laws. As Barnett explained "this was one of the first debates in NZ where 'story' came to the fore and got people going" (Barnett, 2019, n.p.).

The task of building a story about sex workers and decriminalisation for the campaign period fell in part to Anthony Burn, a recent political science graduate. Barnett asked Burn to collect a pool of sex worker testimonials to use in crafting a narrative for the campaign (Burn, 2019). Burn was introduced to New Zealand sex workers who had worked in NSW both before and following decriminalisation. They told Burn their experiences in NSW post-decriminalisation "were always positive" especially when it came to worker safety (Burn n.p). Megan, who worked in NSW's Kings Cross in 1979 remembered the shock of realisation when, following a threat from a client, she was able to appeal to police for support following the repeal of street-based soliciting laws. She also recalled with some satisfaction her last payoff to the vice squad for protection (Megan, 2019). Megan was also prepared to talk about her sex industry experience with the media. Burn carefully marked her anecdotes for future use. What struck him overall was that there was no "typical sex worker" but instead at least five or six different profiles (Burn, 2019, n.p.). There were those he was familiar with through media reports who "came from broken homes, terrible backgrounds and living very rough on the streets" and others like the "bored, middle-aged housewives who had a very nice time as they described" (n.p.). He realised that "actually one-size-fits-all approach" (n.p) was not adequate in building a sex worker profile nor did it work with clients. He would need to build several profiles but this he thought would be the strength of the campaign. A broader and more diverse picture of those involved in the sex industry could help to inform and disrupt accepted discourses and alert MPs and the public to the complexity of the sex industry. Perhaps, they might rethink their opposition. He was also on the look-out for sex workers and their allies willing to appear on panels at town hall events (Burn, 2019).

Jan Logie, then the Executive Director of the Aotearoa YWCA, was a willing participant. She appeared with the NZPC at public meetings and joint press conferences. As someone who had once considered sex work, she thought she was prepared for anti-sex work arguments but found that her message was lost in emotional debates where "Christian conservatives told the stories of ex-sex workers who 
had been traumatized" (Logie, 2019, n.p.). She found these public meetings very difficult but was struck with how the NZPC handled the pressure "their dignity and ability to just not take any of that on and speak to the experience of the workers was quite a model for me" (n.p.).

Logie was not the only ally caught off guard by opponents of the PRA. Burn was intrigued when he found that there were similarities between the types of groups that had opposed the decriminalisation of prostitution in NSW in the late 1980s, and those in NZ a decade later (Burn, 2019). For instance, he observed that in NZ, some feminists had formed an informal alliance with the broadly Christian political lobby group Maxim to argue against decriminalisation. As one of his tasks was to lobby groups and stakeholders outside of Barnett's parliamentary patch, in particular, those whose views were wavering, he took opportunities to meet with his more influential feminist friends to discuss the reasons for their opposition. They accused him of selfinterest and argued that if the sale of sex was understood as legitimate work, then violence against women was being condoned. They insisted that selling sex could never be voluntary, and those sex workers who defended it as a 'choice' were in a state of false consciousness. Burn (2019, n.p.) drew on these discussions to rehearse his own arguments "...it did allow me to keep pushing at this topic even in my own thinking". But while his arguments were being tested behind the scenes, it was Tim Barnett who suffered public attacks for being anti-feminist. As Burn remembers, this was demonstrated most vividly on late night TV when media personality Pam Corkery questioned Barnett's role:

Essentially she said to Tim 'as a gay man you shouldn't even have a dog in this fight, you have no sympathy no understanding of what it's like' so I think that caused pause for other MP's who thought I don't want to face that sort of hostility. (Burn, 2019, n.p.).

In 2010, Burn wrote about his experiences with the PRA campaign and the alliance between feminists and Maxim against decriminalisation:

If there is one key campaign lesson I would immediately draw from the New Zealand experience it is that the debate over prostitution reform can be highly emotive, sensational and irrational. Arguments in favour, therefore, have to be ready to provide irresistible case studies embedded into highly compelling emotional narratives to counter the emotional fire storm that comes from the opposition. (Burn, 2010, n.p.).

\section{Morals and Last-Minute Doubts}

Abel claims that the NZPC and those supporting them took the decision that there would be "no engagement in a moral discourse on sex work by those pushing for decriminalization besides the argument that Parliament should not be in the business of legislating morals" (Abel, 2014, p.3). But appeals to morality were certainly used by the Bill's opponents, and in the final vote, it was 'morality' that placed the PRA on a knife's edge. Days before the final vote, more than 30 church leaders including Catholic and Anglican Bishops signed an open letter to Parliament urging MPs to throw out the PRB. According to the Dominion Post newspaper, this was part of a campaign where MPs were bombarded with hundreds of emails and letters by opponents of the bill (MP's blitzed in prostitute fight, 2003).

The next morning, Tim Barnett counted three MPs whose vote remained uncertain, but as the Bill's sponsor, he was allowed to nominate the final speaker on the day, and this would turn out to be his secret wild card (Barnett, 2019). MP Winnie Laban had voted against the Bill on two previous occasions, but at the last moment, she secretly confided to Barnett that she'd experienced a "crisis of consciousness" and that she would now speak in the Bill's favour (Laban, 2019).

As New Zealand's first female, Pasifika MP Winnie Laban came from a churchgoing family that included two missionaries, and she told me her electorate included "every shade of diversity" (Laban, 2019, n.p.) including her own Pasifika community which was "95 percent Christian" (n.p.). Laban had been under extreme pressure from Church leaders, her Pasifika electorate and some feminist parliamentarians to reject the Bill. Her wavering on the Bill had already prompted rebuttals in meetings, phone calls and public attacks on Samoan language radio:

...they were saying that prostitution was not acceptable and if I was to support it, it means that I make it legitimate for our children. That is what some people put to me - that I was pushing prostitution and encouraging it as well. (Laban, 2019, n.p.).

But as the final vote approached, Laban's empathy for sex workers was palpable. Winnie Laban's name was added to the "wavering MP's list" (Laban, 2019, n.p.) and a meeting was arranged between her, NZPC representative Annah Pickering and trans street-based sex worker Layla, both people of colour. As Annah Pickering explained the NZPC position was:

...if we're going to talk with brown people we got to talk with our own people because if anyone is going to hear our stories and understand the disparities it's them. (Pickering, 2019, n.p.)

As stories were shared, the meeting was extended because according to Annah "there was a lot of crying" (Pickering, 2019 , n.p.) not only about harsh treatment from police towards trans workers on the street but about discrimination 
towards Pasifika workers. Brothel managers had urged Annah to lie about her background and tell clients that she was from Jamaica or Mauritius, in effect to deny her culture and community. Alongside this, the working conditions in the massage parlours were always on the side of the owner. Harsh fines were imposed for the smallest incursions, such as being a little late or if they called in sick without a medical certificate and "when we had our period we had to work" (n.p.). Layla confirmed what Winnie already knew from her family and friends, that street-based sex work was the one area where trans people like herself could make "decent money" and that some of this money also supported families back on the islands. At the meetings end, a Māori prayer was said: "we call it 'Karakia', or 'prayer' and we say it before we meet and after to close that space respectfully", Annah explained, "if you're white you wouldn't do that" (Pickering, 2019, n.p.).

According to Laban, the tears flowed on both sides of her desk "because of the cultural connections - it's all about linkage and family connection" (2019, n.p.). She remembered that as a "brown woman", she had advocated social justice for $98 \%$ of her life:

I remembered kind of praying, thinking on my own hypocrisy here I am voting against those very values that I worked very hard to maintain. So, if I preach exclusion then that legitimises people excluding me or the community that I represent as well. (Laban, 2019, n.p.).

She knew from her family that "her people" worked as sex workers "and they have every right to be protected and that their choice of paid work is a legitimate profession and that they be kept safe and that they have access to good health and supports" (n.p.). According to Laban, it was the NZPC who "look after our people and everyone who worked in the trade and so they were a turning point for me" (n.p.). Though she told no one but her husband and Tim Barnett, her last and final speech would be the deal breaker for the Bill. In it, Laban described how she:

...talked with, and listened to, many prostitutes and others in the sex industry and been particularly touched by the stories of several Polynesian transsexuals and Fa'afafine. Their stories tell me that the current laws serve to make their working life unsafe, and to increase the risk in a risky occupation. They are struggling to live a life of dignity. The current laws do not protect them. Whilst this bill has its imperfections, it does provide greater protection for prostitutes and affords them the same rights as other workers. (New Zealand Government, 2003 n.p.).

Following Laban's speech, the ballot was taken, and the Prostitution Reform Bill was passed by one vote.

\section{Turning the Enemy}

Following the passage of the PRA in 2003, Paul Fitzharris, one-time Acting Deputy Commissioner of Police in New Zealand was appointed as the chair of the Prostitution Law Reform Committee Review Board which included sex workers as members. Drawing on research, field observations and submissions, the committee was to report back to the government on the impact of the PRA within 3-5 years. Accordingly, the Prostitute Law Reform Committee (PLRC) (Prostitute Law Reform Committee, 2008) needs to be seen as integral to a collaborative governance approach to sex work law reform in New Zealand where sex workers are included as significant partners in the law reform process, policy formation and the ongoing implementation of the laws including any review.

Some years earlier, Fitzharris had watched the debate around the PRA but only as an "interested member of the public" and thought prostitution law reform "a pretty good move." Why? "Because I saw what was happening previously with the law was absolutely almost a waste of time" (Fitzharris, 2019, n.p.). He had watched Catherine Healy on the television and thought she was "a pretty interesting woman and very articulate and seemed to know what she was talking about, so I was very pleased to meet her at that time and hear her view" (n.p.).

But although he could see the need for change, he was not sure that decriminalisation was the way forward. He wrote that, at the time of his appointment in 2003, "I was, in fact, initially dubious about the reform but changed my personal view in support of it after seeing the findings emerge from the research that was being carried out as part of the law review process" (Fitzharris \& Taylor, 2010, p.110). By this time, Fitzharris' days with Wellington Vice were decades past and he had had little contact with sex workers in his career since. But when asked in 2019 what informed his attitudes towards sex work, it was an impromptu meeting with a street-based sex worker that stuck in his mind.

In the late 1990s as Canterbury Police District Commander, Fitzharris and his wife moved to a new townhouse in Manchester Street, Christchurch. By coincidence, this same street was where sex workers had recently begun to solicit for clients, and soon after he and his wife had taken up residence, there were a number of sex workers operating directly outside their house. On this day, he noticed a car parked on the grass verge outside his window and concerned about possible damage to a newly planted tree, he left the house for a closer look. As he did, a young woman emerged from the car and approached him, "she said, 'You know why I work here?' I said 'No.' She said 'I work here because I know you're here. If I get into trouble, I know I can knock on your door and get some help" (Fitzharris, 2019 , n.p.). Paul Fitzharris then listened on "amazed" as 
the young woman volunteered information about her parents (who he knew of) and explained that she was doing sex work to enable her son to attend a good school. As he described it "she was articulate and charming ...she told me her story - yea - which was kind of interesting and then that starts to work on my mind, why these people are in this business" (n.p.).

As Fitzharris observed, this casual encounter masked extraordinary circumstances. Firstly, at the time this occurred, soliciting for sex was criminalised under the 1981 Summary Offences Act. In approaching the most senior police officer in the district from her preferred 'spot' outside his home, the young woman had deliberately exposed herself to being apprehended and charged for soliciting. Secondly in identifying her parents and her status as a single parent, she was opening herself up to some risk, in that Fitzharris would have the power to 'out' her to her parents and identify her to Child Youth and Family Services (CYFS). He did neither, but years later, Paul Fitzharris would recall how this incident changed his previously held views on sex workers: "people are there for a whole variety of reasons and you shouldn't put them all in one bag that they're all drug addicts or dropouts, because this woman certainly wasn't that and I learnt to see it" (Fitzharris, 2019, n.p.).

The review found that the PRA had been effective in "achieving its purpose and that the majority of people involved in the sex industry were better off under the PRA than they were under a criminalised system" (Fitzharris \& Taylor, 2010, p.114), but according to Fitzharris, the general populace was still to come to terms with why sex work should be treated as a legitimate occupation: "people needed to realise that many prostitutes, particularly those on the streets, enjoyed their work," he told a NZ news website in 2012 (Hookers happy with law change, 2009, n.p.), but conceded that when he repeated this observation to mainstream New Zealanders "they are absolutely gobsmacked that they would feel that way" (n.p.).

\section{Discussion}

This article has shed light on various factors which motivated key allies to support and engage with the NZPC and other sex workers in a collaborative effort to decriminalise New Zealand's sex industry.

This process required the forging of alliances and networks of influence, and in order for this to occur, it was essential for the NZPC to establish its legitimacy and credibility as an organization able to represent the experiences and concerns of sex workers and articulate them in private and public arenas. It did this through its capacity to educate key allies about the diversity and reality of sex workers' working lives, its projection of a calm and measured leadership style and a commitment to keeping "elbows on the table" (Healy, 2019, n.p.) even where compromise was required.

According to these allies, there were benefits on a personal and professional level which flowed from their support of, and collaborations with sex workers. Acting on the insights they were given into sex work, most non-sex worker interviewees have taken the opportunity to endorse and defend decriminalisation in human rights forums, universities, parliaments and committees in $\mathrm{NZ}$ and on the international stage. But support for sex workers and the PRA also brought attacks on their reputations and integrity. They were accused of being misogynist, of supporting sex work as a career path for school leavers and for enabling sexual exploitation of vulnerable populations.

Despite the reputational costs, the NZPC was able to rely on their support in building the campaign for law reform. Crucially, it was also able to persuade other allies to come on board once the Bill had been introduced to Parliament, partly through drawing on research, and partly through building a narrative, deploying sex workers' personal testimonies to illustrate the consequences of criminalisation for workers.

But what about the sex workers? How did this collaborative process play out for them? My research suggests that, while they were able to form effective alliances and participate in a collaborative governance approach to law reform, the motivations and aims of sex workers and their allies diverged in some important respects. In an interview in 2012, Catherine Healy reflected "...for us to work, and get the people on side, and take them to Tim Barnett, who then pushed it through the Parliament and so on, it was massive. It was huge. I think of all those different meetings and fora and people that I had to stand up in front of" (Wilton, 2009-2016, n.p.). But along with the elation and relief, Healy was aware that, in this case, collaborative governance fell short of removing discriminatory approaches that would satisfy a full decriminalisation label:

Healy: ...we've got a hybrid - we are on the trajectory. We've certainly managed to get rid of the big antisex work sex worker pieces of legislation that existed on our statute books: brothel keeping, living on the earnings, procuring and soliciting, we're on that trajectory for full decriminalisation but we certainly haven't achieved it.

Aroney: You can still work at it? Chip away at it? Healy: Absolutely. I think the foot's in the door, it's firmly wedged, and the evidence is there that we need to change ...particularly with the migrant population, particularly around protections and discrimination. And that's achievable. (Healy, 2019, n.p.) 
As Healy's comments show, decriminalisation can be an ongoing process. This research also suggests that there are limits to a collaborative governance approach when SWROs, in order to build alliances, and maintain them in the process of shepherding law reforms through parliament, find themselves obliged to support the harm minimisation narratives of their allies, rather than foregrounding their commitment to the achievement of full human and civil rights for all sex workers as the fundamental goal of law reform.

\section{Conclusion}

This article has drawn on experiences and events that occurred over a decade ago, so it would be fair to say that some lessons have already been learnt. In retrospect, the NZPC recognises that it should have anticipated the significant differences between NGOs and political allies, and set some ground rules concerning communication and negotiation, especially during the campaign period.

If there was one shared response in the policy community in NZ, it was that a more explicit terminology around sex work policy is needed. Researchers have already adopted Östegren's (2017) approach to policy reform which demonstrates how the various tools of governance are formulated and implemented, and how they impact the sector over the short and long term. This article suggests that those involved in collaborative governance sex work law reform projects could also follow their example and consider adopting Östegren's typology of repressive, restrictive or integrative approaches to sex work law reform in negotiations that concern regulation and policies. This could enable sex worker rights organisations and their allies to expand their role beyond defending decriminalisation and alleviating morality politics to an approach that involves the elaboration of design and aims to "clarify the kinds of measures that would be most effective in alleviating the problems facing the sector, such as stigma, violence and exploitation" (Östegren, 2017, p.25). It also necessitates ongoing formal collaborative governance between sex workers, governing and regulatory bodies following the implementation of reforms, and includes provision for anti-discrimination laws for sex work as an occupation-neither which happened in New Zealand.

Funding Partial financial support was received from The New Zealand Prostitutes Collective.

Availability of Data and Material New Zealand Prostitutes Collective, private archive.

\section{Declarations}

Ethical Approval The study was approved by the University of Technology ethics committee UTS HREC REF NO. ETH18-2570, and the study was performed in accordance with the ethical standards as laid down in the 1964 Declaration of Helsinki and its later amendments.

Competing Interest The author declares that there are no competing interests.

\section{References}

Abel, G. (2014). A decade of decriminalization: Sex work "down under" but not underground. Criminology and Criminal Justice, 14(5), 580-592. https://doi.org/10.1177/1748895814523024

Abel, G. (2018). The problem with sex work policies. Archives of Sexual Behavior, 48, 1925-1929. https://doi.org/10.1007/ s10508-018-1366-5

Abel, G., Fitzgerald, L., \& Healy, C. (2010). Taking the crime out of sex work. Bristol University Press. https://doi.org/10.2307/j. ctt9qgqkd

Ansell, C., \& Gash, A. (2008). Collaborative governance in theory and practice. Journal of Public Administration Theory and Practice, 18(4), 543-571. https://doi.org/10.1093/jopart/mum032

Armstrong, L., Abel, G., \& Roguski, M. (2020). Fear of trafficking or implicit prejudice? Migrant sex workers and the impacts of Section 19. In Sex Work and the New Zealand Model: Decriminalisation and Social Change (pp. 113). Bristol, UK: Policy Press. https://doi.org/10.2307/j.ctv1453kvn.11

Armstrong. L. (2019). Interview with Lynzi Armstrong/Interviewer: Eurydice Aroney [audio recording]. NZPC archive: Wellington, New Zealand.

Aroney, E., \& Crofts, P. (2019). How sex worker activism influenced the decriminalisation of sex work in NSW, Australia. International Journal for Crime, Justice Social Democracy, 8(2), 50. https://doi.org/10.5204/ijcjsd.v8i2.955

Barnett, T. (2019). Interview with Tim Barnett/Interviewer: Eurydice Aroney [audio recording]. NZPC archive: Wellington, New Zealand.

Barnett, T., Healy, C., Reed, A., \& Bennachie, C. (2010). Lobbying for decriminalisation. In Taking the crime out of sex work: New Zealand sex workers' fight for decriminalisation (pp. 57-73). Bristol, UK: Policy Press. https://doi.org/10.1332/policypress/ 9781847423344.003.0004

Benoit, C., Smith, M., Jansson, M., Healey, P., \& Magnuson, D. (2019). "The prostitution problem": Claims, evidence, and policy outcomes. Archives of Sexual Behavior, 48(7), 1905-1923. https:// doi.org/10.1007/s10508-018-1276-6

Burn, A. (2010). Prostitute law reform [blog post]. Retrieved from http://jourdemayne.blogspot.com/2010/12/prostitution-lawreform.html

Burn, A. (2019). Interview with Anthony Burn/Interviewer: Eurydice Aroney [audio recording]. NZPC archive: Wellington, New Zealand.

Coleman, W. D., \& Perl, A. (1999). Internationalized policy environments and policy network analysis. Political Studies, 47(4), 691-709. https://doi.org/10.1111/1467-9248.00225

Crofts, P., Maher, J., Pickering, S., \& Prior, J. (2012). Ambivalent Regulation: The sexual services industries in NSW and Victoria-sex work as work, or as special category? Current Issues in Criminal Justice, 23(3), 393-412. 
Decker, M. R., Crago, A. L., Chu, S. K., Sherman, S. G., Seshu, M. S., Buthelezi, K., \& Beyrer, C. (2015). Human rights violations against sex workers: burden and effect on HIV. The Lancet, 385(9963), 186-199. https://doi.org/10.1016/S0140-6736(14) 60800-X

Diamond, R. (2019). No more fears of police: South Australia is close to fully decriminalising sex work. The Conversation AU. Retrieved from https://theconversation.com/no-more-fearof-police-south-australia-is-close-to-fully-decriminalisingsex-work-119018

Donovan, B., Harcourt, C., Egger, S., Watchirs Smith, L., Schneider, K., Kaldor, J.M., Chen, M.Y., \& Fairley, C.K. (2012). The sex industry in New South Wales: A report to the NSW Ministry of Health. Retrieved from https://kirby.unsw.edu.au/report/nsw-sexindustry-report-2012

Farley, M. (2009). Theory versus reality: Commentary on four articles about trafficking for prostitution. Women's Studies International Forum, 32(4), 311-315. https://doi.org/10.1016/j.wsif.2009.07. 001

Fitzharris, P., \& Taylor, A. (2010). Chapter 7: Review of the Prostitution Reform Act. In G. Abel (Ed.), Taking the Crime out of Sex Work (pp. 105-118). Bristol, UK: Policy Press. https://doi.org/ 10.2307/j.ctt9qgqkd.12

Fitzharris. P. (2019). Interview with Paul Fitzharris/Interviewer: Eurydice Aroney [audio recording]. NZPC archive: Wellington, New Zealand.

Frances, R., \& Gray, A. (2007). 'Unsatisfactory, discriminatory, unjust and inviting corruption'. Feminists and the decriminalisation of street prostitution in New South Wales. Australian Feminist Studies, 22(53), 307-324. https://doi.org/10.1080/08164640701393223

Geymonat, G. G., \& Macioti, P. G. (2016). Sex workers speak: who listens? Retrieved from https://www.nswp.org/resource/sex-workersspeak-who-listens

Global Network of Sex Work Projects. (2020). Shrinking spaces and silencing voices. Retrieved from https://www.nswp.org/sites/nswp.org/files/ shrinking spaces bp.pdf

Greer. G. (2019). Interview with Gill Greer/Interviewer: Eurydice Aroney [audio recording]. NZPC archive: Wellington, New Zealand.

Harcourt, C., \& Donovan, B. (1996). The female sex industry in Australia: A health promotion model. Venereology, 9(1), 63.

Healy, C. (2019). Interview with Catherine Healy/Interviewer: Eurydice Aroney [audio recording]. NZPC archive: Wellington, New Zealand.

Healy, C., Wi-Hongi, A., \& Hati, C. (2017). It's work, it's working: The integration of sex workers and sex work in Aotearoa/New Zealand. Womens Studies Journal, 31(2).

Hookers happy with law change. (2009). Stuff.co.nz. Retrieved from http://www.stuff.co.nz/national/505251/Hookershappy-with-law-change

Jackson, C. A. (2019). "Sex workers unite!": US sex worker support networks in an era of criminalization. Women's Studies Quarterly, 47(3), 169-188. https://doi.org/10.1353/wsq.2019.0049

Jenny. (2019). Interview with Jenny/Interviewer: Eurydice Aroney [audio recording]. NZPC archive: Wellington, New Zealand.

Johnson, G. F. (2015). Governing sex work: An agonistic policy community and its relational dynamics. Critical Policy Studies, 9(3), 259-277. https://doi.org/10.1080/19460171.2014.968602

Kerrigan, D., Kennedy, C. E., Morgan-Thomas, R., Reza-Paul, S., Mwangi, P., Win, K. T., \& Butler, J. (2015). A community empowerment approach to the HIV response among sex workers: effectiveness, challenges, and considerations for implementation and scale-up. The Lancet, 385(9963), 172-185. https://doi.org/10. 1016/S0140-6736(14)60973-9
Laban. W. (2019). Interview with Dame Winnie Laban/Interviewer: Eurydice Aroney [audio recording]. NZPC archive: Wellington, New Zealand.

Levy-Aronovic, S., Lahav-Raz, Y., Raz, A. (2020). Who takes part in the political game? the sex work governance debate in Israel Sexuality Research and Social Policy 1-11 https://doi.org/10. 1007/s13178-020-00476-4

Lindberg, W. (2019). Interview with Warren Lindberg/Interviewer: Eurydice Aroney [audio recording]. NZPC archive: Wellington, New Zealand.

Logie. J. (2019). Interview with Jan Logie/Interviewer: Eurydice Aroney [audio recording]. NZPC archive: Wellington, New Zealand.

Megan. (2019). Interview with Megan/Interviewer: Eurydice Aroney [audio recording]. NZPC archive: Wellington, New Zealand.

MP's blitzed in prostitute fight. (2003). The Dominion Post. 4.

New Zealand Government. (2003). Parliamentary debates. House of Representatives. Retrieved from https://www.parliament.nz/en/pb/ hansard-debates/rhr/document/47HansD_20030625/volume-609week-28-wednesday-25-june-2003

NZPC. (n.d.). NZPC Auckland Community base to close on 13 November 2020 until at least 16 November 2020. Retrieved from https:// www.nzpc.org.nz/COVID-19-Information

Östergren, P. (2017). From zero-tolerance to full integration: Rethinking prostitution policies (DemandAT Working Paper no.10). Retrieved from https://www.demandat.eu/sites/default/files/ DemandAT_WP10_ProstitutionPoliciesTypology_June2017_0. pdf

Perkins, R., \& Bennett, G. (1985). Being a Prostitute. Allen \& Unwin.

Phipps, A. (2017). Sex wars revisited: A rhetorical economy of sex industry opposition. Journal of International Women's Studies, 18(4), 306-320.

Pickering, A. (2019). Interview with Annah Pickering/Interviewer: Eurydice Aroney [audio recording]. NZPC archive: Wellington, New Zealand.

Prostitute Law Reform Committee. (2008). Report of the Prostitution Law Review Committee on the operation of the Prostitution Reform Act 2003. Retrieved from http://prostitutescollective.net/ wp-content/uploads/2016/10/report-of-the-nz-prostitution-lawcommittee-2008.pdf

Prostitute Reform Bill (2003) (NZ). Retrieved from https://www. parliament.nz/en/pb/bills-and-laws/bills-proposed-laws/ document/00DBHOH_BILL3421_1/prostitution-reform-bill

Radio New Zealand. (2020). Covid-19: Green light for sex industry to restart. Retrieved from https://www.rnz.co.nz/news/national/ 416803/covid-19-green-light-for-sex-industry-to-restart

Raymond, J. G. (2018). Gatekeeping decriminalization of prostitution: The ubiquitous influence of the New Zealand Prostitutes' Collective. Dignity: A Journal on Sexual Exploitation and Violence, 3(2). https://doi. org/10.23860/dignity.2018.03.02.06

Roguski, M. (2013). Occupational health and safety of migrant sex workers in New Zealand Report. Retrieved from https://apo.org. $\mathrm{au} /$ node $/ 34510$

Rottier, J. (2018). Decriminalization of sex work: The New Zealand model: An analysis of the integrative sex industry policy in New Zealand (Aotearoa). Eleven International Publishing.

Scarlet Alliance, Australian Sex Workers Association. (2021). Full decriminalisation of sex work in Australia. Retrieved from https:// scarletalliance.org.au/library/briefing_paper_full_decrim

Scoular, J. (2010). What's law got to do with it? How and why law matters in the regulation of sex work. Journal of law society, 37(1), 12-39. https://doi.org/10.1111/j.1467-6478.2010.00493.x

Shannon, K., Goldenberg, S. M., Deering, K. N., \& Strathdee, S. A. (2014). HIV infection among female sex workers in concentrated and high prevalence epidemics: why a structural determinants 
framework is needed. Current Opinion in HIV AIDS, 9(2), 174. https://doi.org/10.1097/COH.0000000000000042

Skilbrei, M., \& Holmström, C. (2016). Prostitution policy in the Nordic region: Ambiguous sympathies. Routledge. https://doi.org/10. 4324/9781315602608

Smith, M., \& Mac, J. (2018). Revolting prostitutes: The fight for sex workers' rights. Verso Trade.

South Australian Government. (2019). Parliamentary debates. Legislative Council (2019-06-06). Retrieved from http://hansardpublic. parliament.sa.gov.au/Pages/DateDisplay.aspx\#/DateDisplay/ HANSARD-10-26952/HANSARD-10-26931

Sweetman, B. (2017). Reflection from the field: The judicial system and sex work. New Zealand Women's Studies Journal, 31(2), $61-68$.

Vanwesenbeeck, I. (2017). Sex work criminalization is barking up the wrong tree. Archives of Sexual Behavior, 46(6). https:// doi.org/10.1007/s10508-017-1008-3

Wagenaar, H. (2017). Why prostitution policy (usually) fails and what to do about it? Social Sciences, 6(2), 43. https://doi.org/10.3390/ socsci6020043
Wagenaar, H., Amesberger, H., \& Altink, S. (2017). Designing prostitution policy: Intention and reality in regulating the sex trade. Bristol, UK: Policy Press. https://doi.org/10.26530/OAPEN_ 627654

Warnock, C., \& Wheen, N. (2012). Sex work in New Zealand: The re-importation of moral majoritarianism in regulating decriminalized industry. Canadian Journal of Women and the Law, 24(2), 414-438. https://doi.org/10.3138/cjwl.24.2.414

Wilton, C. (2009-2016). Selling Sex: The New Zealand sex industry oral history project. Wellington, New Zealand: Alexander Turnbull Library, National Library of New Zealand. Retrieved from https://tiaki.natlib.govt.nz/\#details=ecatalogue. 968758

Wilton, C. (2018). My Body, My Business: New Zealand sex workers in an era of change. Otago University Press.

Publisher's Note Springer Nature remains neutral with regard to jurisdictional claims in published maps and institutional affiliations. 